\title{
BIODEGRADABLE PLASTIC PRODUCTION FROM POLYHYDROXYBUTYRATE(PHB) PRODUCING BACTERIA AND ITS IMPACT ON ENVIRONMENT.
}

\author{
Hiral Shah \\ Nidhi Gondaliya \\ Richa Soni
}

\begin{abstract}
Plastic materials have been used in various ways such as packaging material, glass wares, certain parts of instruments of various grades, many more. As plastic products are not easily decomposed and accumulate in environment. This has created an adverse effect on our ecosystem. Bioplastics are best alternative to overcome these issues and reduce damages in ecosystem. Bioplastics are easily and speedily degrade under natural environmental conditions. Polyhydroxybutyrate or PHB is a bioplastic, one of the best natural polymer and alternative of synthetic plastic material. Bioplastic are comparative more flexible to convert into various forms also. Normally, it is a lipid reserve material produce in adverse or under stress conditions and stored within the cell wall of micro-organisms. Poly-3-hydroxybutyrate (PHB) is a natural biopolymer produce by wide range of microbes which is a storage granule used by microbes as an energy as well as carbon source.this microbes includes from extremophiles to mesophiles. The objective of our work was to isolate potential PHB producing bacteria using agro-residues as carbon sources within natural environment conditions. This work describes the understanding of microbes that are involved in the degradation of both natural and synthetic polymers. Also to contribute in green environment by providing eco- friendly product.
\end{abstract}

Keywords: Polyhydroxybutyrate, Ecosystem, Bioplastics, Eco-Friendly Product

\section{INTRODUCTION}

Natural polymers (from the Greek poly meaning "many" and meros meaning "parts") are found in many forms such as horns of animals, tortoise shell, shellac ,rosin (from pine trees), asphalt, and tar from distillation of organic materials. One of the most useful of the natural polymers was rubber, obtained from the sap of the hevea tree. Rubber was named by the chemist Joseph Priestley who found that a piece of solidified latex gum was good for rubbing out pencil marks on paper. In Great Britain, erasers are still called "rubbers". Natural rubber had only limited use as it became brittle in the cold and melted when warmed. In 1839, Charles Goodyear discovered, through a lucky accident, that by heating the latex with sulfur, the properties were changed making the rubber more flexible and temperature stable. That process became known as vulcanization (Katz, D.A., 1998). The first synthetic polymer, a 
phenol-formaldehyde polymer, was introduced under the name "Bakelite", by Leo Baekeland in 1909. Its original use was to make billiard balls. Rayon, the first synthetic fiber was developed as a replacement for silk in 1911 (Armitage et al., 1973).

Since synthetic plastics marked their introduce in the 1950 s, they have emerged to be among the most needed material in our daily life. These petroleum-based plastics are very stable in harsh conditions especially against the attack of chemical degradation and microbial decomposition, thus rendering them durable, highly resistant and 'blessed' with a very long life span in the environment. Due to their excellent properties and wide range of application, synthetic plastics have since championed the commodity market and the technologies related to plastics manufacturing are very well established. In fact, it is impossible to imagine everyday life without synthetic plastics.

However, most of these plastics utilize fossil carbon, especially raw petroleum as the starting material and eventually accumulate in the environment when discarded. The accumulation of plastic wastes is evident all over the world where natural ecosystems such as rivers, lakes and mangroves are polluted with these recalcitrant materials. In the tropics, discarded plastics pose an additional problem; they can become excellent breeding locations for mosquitoes when the discarded plastics contain moisture. To overcome issues of pollution and imbalance of nature due to synthetic polymers gradually we need to replace it with biopolymers.

\section{Biopolymers (Bioplastic):}

Thermoplastics produced from renewable agricultural and forest resources (biomass), also called bioplastics, are gaining in importance. For this study, we are investigating the opportunity for biobased thermoplastics in the disposable plastics market segments as opposed to engineering thermoplastics or thermoset plastics/ resins.

In order for a bioplastic to be considered compostable it has to satisfy three criteria:

1) Biodegradation - breaks down into carbon dioxide, water and biomass at the same rate as cellulose

2) Disintegration - the plastic is indistinguishable in the compost from other biomass material after a fixed schedule of time

3) Non Toxic - the residual biomass material must not be harmful to animals or plants in final form

They are polyesters obtained by polymerisation of monomers prepared by fermentation process (semi-synthetic polymers) or produced by a range of microorganisms, cultured under different nutrient and environmental conditions (microbial polymers) (Madison and Huisman, 1999). These materials are accumulated in microorganisms as storage materials.

Most of our study deals with Bacterial polymers of poly(hydroxyalkanoates) (PHAs). the properties of PHB as a biodegradable thermoplastic material have captured attention for more than 20 years, and patents were originally filed in the United States by J. N. Baptist in 1962, the first industrial production of PHB and PHA did not occur until 1982, when ICI plc marketed them under the trade name Biopol. Marchessault et al., (1988) have also drawn attention to the potential role of PHAs as so-called biomass transducers, i.e., their use in the microbial

transformation of carbohydrate feedstock via PHA into chiral depolymerization products 
(Seebach and Zuger, 1982), (Seebach and Zuger, 1985) or small molecule organic chemicals by pyrolysis.

The current sharp focus of attention on the environmental pollution caused by discarded petrochemical plastics has given added force to studies of the biodegradation of PHAs in the natural environment. However, against these important applied aspects there has also been an increasing appreciation of the role of such polymers in the life of microorganisms in their natural habitats.

A number of bacteria can accumulate PHAs as intracellular reserve materials. Some organisms accumulate PHA from $30 \%$ to $80 \%$ of their cellular dry weight, in the presence of an abundant source of carbon and under limited nitrogen (Mercan et al., 2002).

Chen and $\mathrm{Wu}$ (2005) reported that Polyhydroxyalkanoates or PHAs are linear polyesters produced in nature by bacterial fermentation of sugar or lipids. They are produced by the bacteria to store carbon and energy. More than 150 different monomers can be combined within this family to give materials with extremely different properties. These plastics are biodegradable and are used in the production of bioplastics. They can be either thermoplastic or elastomeric materials, with melting points ranging from 40 to $180{ }^{\circ} \mathrm{C}$. The mechanical and biocompatibility of PHA can also be changed by blending, modifying the surface or combining PHA with other polymers, enzymes and inorganic materials, making it possible for a wider range of applications.

Polyhydroxybutyrate (PHB) is a polyhydroxyalkanoates (PHA), a polymer belonging to the polyesters class that was first isolated and characterized in 1925 by French microbiologist Maurice Lemoigne. PHB is produced by microorganisms (like Ralstonia eutropha or Bacillus megaterium) apparently in response to conditions of physiological stress. The polymer is primarily a product of carbon assimilation (from glucose or starch)

\section{MATERIALS AND METHODS}

\section{Sources:}

Soil Samples were collected from different agriculture fields surrounding Kalol, Certain samples were also taken of raw milk from local dairies.

\section{Isolation:}

Serial dilution of each sample was done to obtain well isolated colonies upto $10^{-9}$. Spread plate teachnique was used to isolate microbes. All the prepared diluted samples were spreaded on Nutrient agar plates in duplicates and incubated for 24-48hours at $28-30 \mathrm{C}$.

\section{Identification:}

Well-isolated colonies were picked up and gram-staining was performed to check their types and purity. Furthermore bacterial isolates were qualitatively tested for PHB production following the viable colony method of screening using Sudan Black B dye (Juan et al., 1998). The dark blue coloured colonies were taken as positive for PHB production.

Colony characteristics

Colony characteristics like size, shape, margin, elevation, texture, consistency, opacity and pigmentation were considered for the primary identification of the bacterial isolates capable of producing $\mathrm{PHB}$ 


\section{Confirmation of PHB producing bacterial isolates by PHB staining}

All bacterial isolates were stained by Sudan Black B staining method(Byrom and Byrom, 1991).

\section{Method of staining PHB granules}

1. Spread the culture on a clean,sterile, grease-free slide, using the nichrome wire loop.The smear should cover an area about $10 \mathrm{~mm}$ x $30 \mathrm{~mm}$.

2. Allow the smear to dry in the air. 3. Fix the smear by holding the slide with forceps and passing it horizontally through a small Bunsen flame 2-3 times.

3. Fixing kills the bacteria by coagulating the cytoplasm. It also sticks them to the slide.

4. Place a few drops of Sudan Black solution on the fixed preparation. After 5-10

minutes the ethanol in the stain should have evaporated. Any excess liquid can be carefully drawn off using the edge of a piece of filter paper.

5. Immerse the slide in xylene until it is completely decolorized (this takes about 10 seconds). Allow the slide to dry

6. Flood the slide with the counterstain, Safranin solution for 10 seconds, gently rinse the slide with running water.

7. Allow to air dry the slide completely and examine with an oil immersion lens. The PHB can be seen as very dark granules inside pink cells

\section{Standard Curve For PHB}

Pure PHB was used to obtain standard curve using Law and Slepecky method given in 1961. $1 \mathrm{mg}$ was dissolved in $10 \mathrm{ml}$ of concentrated H2SO4 and heated for $10 \mathrm{~min}$ to convert PHB into crotonic acid, which gave $0.1 \mathrm{mg} / \mathrm{ml}$ concentration.

\section{Polymer (PHB) Extraction. (Law and Slepecky, 1961)}

1. For the assay of polymer in small quantities of cells, the organisms were centrifuged in polypropylene centrifuge tubes which had been previously washed thoroughly with ethanol and hot chloroform to remove plasticizers.

2. The cell paste was resuspended in a volume of commercial sodium hypochlorite solution (Clorox or equivalent) equal to the original volume of medium. 3. After $1 \mathrm{~h}$ incubation at $37^{\circ} \mathrm{C}$, the lipid granules were centrifuged, washed with water followed by washing with acetone and absolute alcohol.

4. Finally, the polymer was dissolved by extraction with three small portions of boiling chloroform, the chloroform solution was filtered, and the filtrate was used for poly- $\beta$-hydroxybutyrate assay.

Spectrophotometric Assay

1. A sample containing extracted polymer in chloroform is transferred to a clean test tube.

2. The chloroform is evaporated and $10 \mathrm{ml}$ of concentrated $\mathrm{H} 2 \mathrm{~S} 04$ is added, the tube is capped with a glass marble and boileded for $10 \mathrm{~min}$ at $100^{\circ} \mathrm{C}$ in a water bath. 3 . The solution is cooled, and after thorough mixing, a sample is transferred to a silica cuvette and the absorbance at $235 \mathrm{~nm}$ is measured against a sulfuric acid blank. 
The most potential bacterial strain was selected which showed highest PHB production determined by the spectrophotometric assay.

Identification

Morphology of the most potential strain producing PHB was determined by Monochrome staining \& Negative staining technique. Also, Gram staining technique was used to check its Gram's reaction. Spore staining was carried out by Bartholomew and Mittwer's method.

while Biochemical characterization of the strain was carried out by using various tests like fermentation of sugars, indole production, methyl red, voges-proskauer, citrate utilization, nitrate reduction, ammonia production, H2S production, lipid hydrolysis, starch hydrolysis, gelatin hydrolysis, urea hydrolysis, dehydrogenation and catalase test. Biochemical tests were carried out as per the method given by (Cappuccino and Sherman, 1992) with 24 h old culture.

\section{RESULTS AND DISCUSSION}

PHB is accumulated by numerous microorganisms and is the best characterized PHA (Madison and Huisman, 1999). 12 different soil samples and 4 raw milk samples were used to obtain desired bacterial isolates. serial dilution upto $10^{-9}$ was useful to obtain isolated colonies with desired properties.

All spreaded plates from various diluted samples were incubated for 24-48 h which yielded maximum and well isolated young growing bacterial colonies. Those colonies were very easily understood for different characteristics.

\section{$\underline{\text { Colony Isolation and characteristics }}$}

PHAs, synthesized by many Gram positive and Gram-negative bacteria as storage compounds, are deposited as insoluble inclusions in the cytoplasm (Steinbuchel, A., 1991). Hartman, T.L. (1940) was the first to suggest the use of Sudan black B, as a bacterial fat stain.

Majority of isolated colonies with desired properties belongs to Azotobacter, Bacillus,Pseudomonas and Archeabacteria species. All of them have different ratio of PHB accumulation. Ralstonia eutropha (formerly Alcaligenes eutrophus) has been the subject of much published research work because it can accumulate PHAs up to 80 per cent dry weight (Lee, S.Y., 1996). All isolates with desired properties were coded PH1 to PH8. Majority of isolates belongs to Bacillus strains, Azotobacter strains, Micrococcus strains and lactobacilli strains.

\section{CONCLUSION}

In the present study, an attempt was made to isolate efficient PHB producing bacteria from samples collected from various sources like soil, water and milk. With a concern to make product economically feasible, cultural parameters like media components and also growth conditions were optimized for the most potential bacterial isolate. Various diluted samples of soil, water and milk were used to isolate PHB producing bacterial strains primarily with the help of Nutrient agar medium because it favours the growth of diverse group of bacteria.

Primary screening of PHB producing bacterial colonies was carried out by using viable colony method with the help of Sudan Black B solution. Total 08 different types of colonies were found as PHB positive strains by using viable colony method. Secondary screening was done 
Towards Excellence: An Indexed, Refereed \& Peer Reviewed Journal of Higher Education / Hiral Shah, Nidhi Gandaliya \& Richa Soni / Page 584-593

with the help of Sudan Black B staining and Quantitative PHB determination by using UV Spectrophotometric assay. All the isolates were showing presence of PHB granules. Different groups of bacteria like, Bacilli, Azotobacter and Micrococci were observed as dominant PHB producers among the isolated strains. One bacterial strain, Bacillus PH5 coded as was found to produce highest PHB among all the other isolated PHB producing bacterial strains. Bacillus PH5 was observed to produce $48 \%$ by using Nutrient broth. 


\section{Works Cited}

Armitage, D.A., Hughes, M.N. and Sinden, A.W. (1973). "The preparation of bouncing putty". J. Chem. Educ., 50, 434.

Byrom, J. and Byrom, D. (1991). "Biopol — Nature's plastic". NCBE Newsletter Summer 1991. 9-11.

Cappuccino, J.C. and Sherman, N. (1992). "Microbiology: A laboratory Manual”., third ed. Benjamin/ cummings pub.co., 125-179.

Chen G.Q. and Wu Q. (2005). "The application of polyhydroxyalkanoates as tissue engineering materials". Biomaterials, 26: 6565-6578

Hartman, T.L. (1940). "The use of Sudan Black B as a bacterial fat stain"., Staining Technology, 15: 23-28.

Katz, D.A. (1998). "Polymers". PA 19035, USA. 1-15.

Lee, S.Y. (1996). "Bacterial Polyhydroxyalkanoates". Biotechnology and Bioengineering, 49: 1-14.

Madison, L.L. and Huisman, G. W. (1999). "Metabolic engineering of polyhydroxyalkanoates from DNA to plastic". Microbial Molecular Biology Reviews, 63: 21-53

Marchessault, R. H., Bluhm,T.L., Deslandes,Y., Hamer, G.K., Orts, W.J., Sundarajan, P.J., Taylor, M.G., Bloembergen, S. and Holden, D.A. (1988). "Poly(,hydroxyalkanoates): biorefinery polymers in search of applications". Makromol. Chem. Macromol. Symp., 19 : 235-254.

Steinbuchel, A. (1991). "Polyhydroxyalkanoic acids : Novel materials from biological sources"., Biomaterials, (Ed) D. Byrom, 124-213.

Seebach, D. and Zuger, M.F. (1982). "Uber die Depolymerisierung von Poly-(R)3hydroxy-buttersaureester (PHB).” Helv. Chim. Acta. 65:495-503.

Seebach, D. and Zuger, M.F. (1985). "On the preparation of methyl and ethyl (R)(-)- 3hydroxy-valerate by depolymerization of a mixed PHB/PHV biopolymer." Tetrahedron Lett., 25:2747-2750

Mercan, N., Aslim, B., Yürsekdag, Z.N. and Beyatli, Y. (2002). "Production of poly $\beta$ hydroxybutyrate (PHB) by some Rhizobium bacteria.” Turk. J. Biol. 26, 215. Law, J. H. and Slepecky, R.A. (1961). "Assay of poly- $\beta$-hydroxybutyric Acid”. J. Bacteriol. 82 : 33-36.

Juan, M. L., Gonzalez, L. W. and Walker, G. C. (1998). "A Novel Screening Method for Isolating Exopolysaccharide deficient Mutants"., Applied and Environmental Microbiology, 64 : 4600-4602. 
Towards Excellence: An Indexed, Refereed \& Peer Reviewed Journal of Higher Education / Hiral Shah, Nidhi Gandaliya \& Richa Soni / Page 584-593

Table 1 Colonial characteristics of PHB producing bacterial isolates

\begin{tabular}{|l|l|l|l|l|l|l|l|}
\hline Colony & Size & Shape & Texture & $\begin{array}{l}\text { Consistenc } \\
\mathrm{y}\end{array}$ & Opacity & Marigin & Pigmentation \\
\hline PH1 & Small & Round & Smooth & Moist & Opaque & Even & Light Yellow \\
\hline PH2 & Intermediate & Round & Smooth & Moist & Opaque & Even/Entire & Reddish \\
\hline PH3 & Small & Round & Smooth & Moist & Transparent & Even & Nil \\
\hline PH4 & Intermediate & Irregular & $\begin{array}{c}\text { Smooth } \\
\text { Glistening }\end{array}$ & Moist & Translucent & $\begin{array}{l}\text { Rhizoid, } \\
\text { Uneven }\end{array}$ & Dull White \\
\hline PH5 & Big & Round & Smooth & Butyrous & Opaque & Uneven & Off White \\
\hline PH6 & Intermediate & Irregular & Rough & Dry & Opaque & Uneven & Nil \\
\hline PH7 & Big & Round & Rough & Dry & Opaque & Undulate & Nil \\
\hline PH8 & Small & Round & Smooth & Moist & Opaque & Entire & Nil \\
\hline
\end{tabular}

\section{Standard graph of PHB UV-Spectrophotometeric assay}

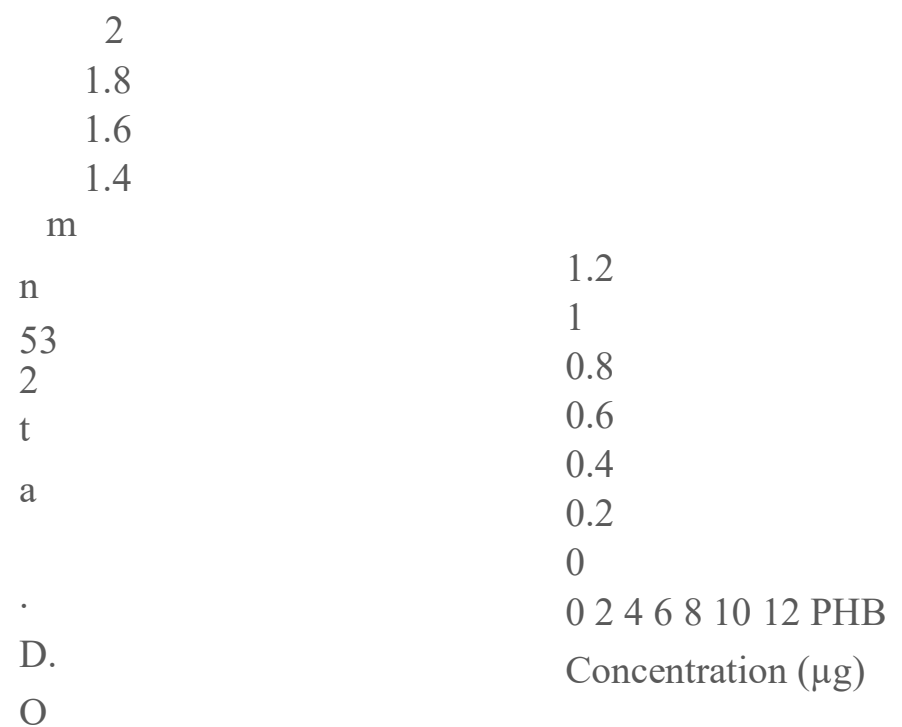


Table 2: Dry Cell Weight and PHB production in N-broth by selected strains after incubation of $48 \mathrm{~h}$ at $30^{\circ} \mathrm{C}$.

\begin{tabular}{|c|c|c|c|c|}
\hline Isolates & $\begin{array}{l}\text { Probable } \\
\text { strain }\end{array}$ & $\begin{array}{l}\text { Dry cell } \\
\text { weight(g/ } \\
\text { 1) }\end{array}$ & $\operatorname{PHB}(\mathrm{g} / \mathrm{l})$ & PHB \% \\
\hline PH1 & Azotobacter & 0.826 & 0.313 & 31 \\
\hline PH2 & $\begin{array}{l}\text { Micrococcu } \\
\mathrm{S}\end{array}$ & 0.761 & 0.106 & 17 \\
\hline PH3 & $\begin{array}{l}\text { Micrococcu } \\
\mathrm{S}\end{array}$ & 0.553 & 0.209 & 21 \\
\hline PH4 & Bacillus & 0.451 & 0.089 & 10 \\
\hline PH5 & Bacillus & 0.813 & 0.489 & 48 \\
\hline PH6 & Bacillus & 0.713 & 0.239 & 26 \\
\hline PH7 & Bacillus & 0.745 & 0.110 & 19 \\
\hline PH8 & Azotobacter & 0.859 & 0.473 & 43 \\
\hline
\end{tabular}

\section{Hiral Shah}

Assistant Professor

Department of Microbiology

Ananya Institute of Science, Kalol

\&

Nidhi Gondaliya \& Richa Soni

*Corresponding Author

Assistant Professor,

Department of Life science 
Towards Excellence: An Indexed, Refereed \& Peer Reviewed Journal of Higher Education / Hiral Shah, Nidhi Gandaliya \& Richa Soni / Page 584-593

School of Science,

Gujarat University, Ahmedabad, Gujarat

nidhi13285gondaliya@gmail.com

March, 2021. VOL.13. ISSUE NO. 1 https://hrdc.gujaratuniversity.ac.in/Publication $\quad$ Page | 593 